\title{
A community resource for high-throughput quantitative RT-PCR analysis of transcription factor gene expression in Medicago truncatula
}

\author{
Klementina Kakar ${ }^{1}$, Maren Wandrey ${ }^{1}$, Tomasz Czechowski ${ }^{1}$, Tanja Gaertner ${ }^{1}$, \\ Wolf-Rüdiger Scheible ${ }^{1}$, Mark Stitt ${ }^{1}$, Ivone Torres-Jerez ${ }^{3}$, Yongli Xiao ${ }^{2}$, \\ Julia C Redman², Hank C Wu², Foo Cheung ${ }^{2}$, Christopher D Town ${ }^{2}$ and \\ Michael K Udvardi*1,3
}

\begin{abstract}
Address: ${ }^{1}$ Max-Planck Institute of Molecular Plant Physiology, Am Mühlenberg 1, 14476 Potsdam-Golm, Germany, ${ }^{2}$ The J. Craig Venter Institute, 9704 Medical Center Drive, Rockville, MD, 20850, USA and ${ }^{3}$ The Samuel Roberts Noble Foundation, 2510 Sam Noble Parkway, Ardmore, OK, 73401, USA

Email: Klementina Kakar - kakar@mpimp-golm.mpg.de; Maren Wandrey - wandrey@gfz-potsdam.de; Tomasz Czechowski - tc519@york.ac.uk; Tanja Gaertner - gaertner@mpimp-golm.mpg.de; Wolf-Rüdiger Scheible - scheible@mpimp-golm.mpg.de; Mark Stitt - stitt@mpimpgolm.mpg.de; Ivone Torres-Jerez - itjerez@noble.org; Yongli Xiao - yxiao@jcvi.org; Julia C Redman - jredman@jcvi.org;

Hank CWu - hwu@jcvi.org; Foo Cheung - FCheung@jcvi.org; Christopher D Town - cdtown@jcvi.org;

Michael K Udvardi* - mudvardi@noble.org

* Corresponding author
\end{abstract}

Published: 8 July 2008

Plant Methods 2008, 4:18 doi:10.1 186/1746-48|I-4-18

This article is available from: http://www.plantmethods.com/content/4/I//8

(c) 2008 Kakar et al; licensee BioMed Central Ltd.

This is an Open Access article distributed under the terms of the Creative Commons Attribution License (http://creativecommons.org/licenses/by/2.0), which permits unrestricted use, distribution, and reproduction in any medium, provided the original work is properly cited.
Received: 15 April 2008

Accepted: 8 July 2008

\begin{abstract}
Background: Medicago truncatula is a model legume species that is currently the focus of an international genome sequencing effort. Although several different oligonucleotide and cDNA arrays have been produced for genomewide transcript analysis of this species, intrinsic limitations in the sensitivity of hybridization-based technologies mean that transcripts of genes expressed at low-levels cannot be measured accurately with these tools. Amongst such genes are many encoding transcription factors (TFs), which are arguably the most important class of regulatory proteins. Quantitative reverse transcription-polymerase chain reaction (qRT-PCR) is the most sensitive method currently available for transcript quantification, and one that can be scaled up to analyze transcripts of thousands of genes in parallel. Thus, qRT-PCR is an ideal method to tackle the problem of TF transcript quantification in Medicago and other plants.

Results: We established a bioinformatics pipeline to identify putative TF genes in Medicago truncatula and to design gene-specific oligonucleotide primers for qRT-PCR analysis of TF transcripts. We validated the efficacy and gene-specificity of over 1000 TF primer pairs and utilized these to identify sets of organ-enhanced TF genes that may play important roles in organ development or differentiation in this species. This community resource will be developed further as more genome sequence becomes available, with the ultimate goal of producing validated, gene-specific primers for all Medicago TF genes.

Conclusion: High-throughput qRT-PCR using a 384-well plate format enables rapid, flexible, and sensitive quantification of all predicted Medicago transcription factor mRNAs. This resource has been utilized recently by several groups in Europe, Australia, and the USA, and we expect that it will become the 'gold-standard' for TF transcript profiling in Medicago truncatula.
\end{abstract}




\section{Background}

Legumes are second only to grasses in agricultural importance [1]. They are a mainstay of sustainable agricultural systems because of their ability to reduce atmospheric nitrogen $\left(\mathrm{N}_{2}\right)$ to ammonia via a symbiosis with bacteria called rhizobia. This provides legumes and subsequent crops with a free and renewable source of nitrogen in lieu of expensive, environmentally-unfriendly fertilizers. Development and differentiation of root nodules, the organ that accommodates nitrogen-fixing rhizobia in legumes, is orchestrated by transcription factors [2-9]. Transcription factors are DNA-binding proteins that regulate the transcription of most, if not all genes [10]. As a result, TFs play central roles in all aspects of plant biology, including development and differentiation of organs and adaptive responses to changes in the environment [11]. Transcription factors as a whole are an important target of plant research because they are a key to understanding the regulation of important plant processes as well as potential tools to optimize these processes for agriculture.

The importance of TFs in plant biology is reflected by the fact that approximately $5 \%$ of all plant genes encode such proteins [10]. Thus, even species with relatively small genomes, such as Arabidopsis thaliana contain thousands of TF genes [10]. This presents a real challenge for systematic approaches to decipher the function of TF genes in plants. Classical, 'forward' genetics has uncovered the roles of perhaps a hundred TF genes in Arabidopsis [12] and far fewer in other species [11]. Reverse-genetic approaches, using T-DNA insertion mutants for instance [13], provide a means to decipher in a systematic and relatively rapid manner the function of TF genes/proteins, although gene-redundancy often stymies this enterprise [12]. Another stumbling-block is that phenotypes associated with non-redundant TFs may be subtle in nature.

Transcript profiling can help to uncover the functions of TF genes/proteins by revealing where and when in a plant TF genes are expressed. This information can help direct our attention to particular organs, developmental stages, or conditions under which aberrant phenotypes might become apparent in a TF mutant of interest.

Medicago truncatula is a model legume species that is currently the focus of an international genome sequencing effort [14]. Several generations of cDNA [15] and oligonucleotide arrays [16] have been developed for transcriptome analysis of Medicago truncatula, including mostrecently an Affymetrix GeneChip that contains 51,000 probe-sets representing a large proportion of all the genes in this species [17]. While these tools now provide a means to measure the transcriptional output of a large proportion of genes in Medicago, inherent limitations in the sensitivity of hybridization-based technologies [18] mean that transcripts of a substantial number of genes cannot be detected even when probes for these transcripts are present on the array/chip. Furthermore, expansion of arrays to encompass novel genes uncovered by genome sequencing is not a trivial task. An alternative to arrays that is $2-3$ orders of magnitude more sensitive and more flexible in terms of expansion to encompass novel genes is quantitative reverse transcription-polymerase chain reaction (qRT-PCR). Platforms for qRT-PCR analysis of thousands of Arabidopsis and rice TF genes have been developed by us and others $[19,20]$, and utilized to identify TF genes involved in Arabidopsis responses to nutrient stress and pathogen attack [21-24]. Here we describe a bioinformatics pipeline to identify putative TF genes in Medicago truncatula and to design gene-specific oligonucleotide primers for qRT-PCR analysis of all predicted TF transcripts. Over $1000 \mathrm{TF}$ primer pairs were tested and used to identify sets of organ-enhanced TF genes that may play important roles in organ development or differentiation in this species.

\section{Results and Discussion}

\section{Identification of putative transcription factors}

TF protein families are generally defined by the type(s) of DNA-binding domain they contain and putative TF genes are often identified on the basis of DNA sequences that encode known DNA-binding domains [10,11,25,26]. We utilized this approach to identify putative TFs of Medicago amongst the set of proteins predicted from genomic sequence by the International Medicago Genome Annotation Group (IMGAG). Proteins of IMGAG release 1, which contained over 40,000 predicted proteins, were screened for the presence of known or presumed DNA-binding domains (Table 1), using INTERPRO [27]. Medicago proteins containing putative DNA binding domains and other domains associated with TFs were then used as query sequences in WU-BLASTX [28] which included searches of both the non-redundant DNA database of NCBI [29] and the well-curated protein database, UniProt [30] to check annotations of related proteins in support of tentative Medicago TF assignments. This process resulted in a list of 1045 putative TF genes (see Additional file 1). We utilized genomic sequences rather than the large collection of partial cDNA sequences present in Expressed Sequence Tag (EST) databases for Medicago as the starting point for TF gene discovery because protein sequences derived from genomic sequence are more complete and the set of IMGAG proteins essentially contains no redundancy. Although identification of the 'complete' set of Medicago TFs from IMGAG-annotated proteins will only be possible upon completion of genome sequencing, we expect little or no redundancy in the protein set targeted by our primer set. This approach avoids wasting money on redundant primer sets and re-organization of primers when redundancy is detected, both of which would have 
Table I: Classification of putative transcription factors of Medicago into families and sub-families

\begin{tabular}{|c|c|c|c|c|}
\hline TF Family & $\begin{array}{l}\text { No. of } \\
\text { Genes }\end{array}$ & $\begin{array}{l}\text { Characteristic Domain } \\
\text { (InterPro No.) }\end{array}$ & $\begin{array}{l}\text { Domain } \\
\text { Function }\end{array}$ & Domain Description \\
\hline MYB/HD-like & 76 & IPR00I005, IPR009057 & $\mathrm{D}$ & Myb, DNA-binding; homeodomain like \\
\hline MYB & 58 & IPR00I005 & $\mathrm{D}$ & Myb, DNA-binding \\
\hline $\mathrm{C}_{2} \mathrm{H}_{2}(\mathrm{Zn})$ & 64 & IPR007087 & NA & $\mathrm{Zn}$-finger, $\mathrm{C} 2 \mathrm{H} 2$ type \\
\hline AP2/EREBP & 55 & IPR00 I 47 I & $\mathbf{D}$ & $\begin{array}{c}\text { Pathogenesis-related transcriptional factor and } \\
\text { ethylene response factor }\end{array}$ \\
\hline BHLH & 49 & IPR00I092 & $\mathrm{D}$ & Basic helix-loop-helix dimerisation region bHLH \\
\hline HD-like & 50 & IPR009057 & $\mathrm{D}$ & Homeodomain like \\
\hline HD family & & IPR00I356 & $\mathrm{D}$ & Homeobox \\
\hline HD & 25 & & & \\
\hline HD-ZIP & 5 & IPR0067I2 & $P$ & HD-ZIP protein, $\mathrm{N}$ terminus \\
\hline HD-PHD finger & 2 & IPR00I965 & $P$ & Zn-finger like, PHD-finger \\
\hline MADS & 48 & IPR002I00 & $\mathrm{D}$ & TF, MADS-box \\
\hline BZIP & 41 & IPR004827 & $\mathrm{D}$ & Basic Leu zipper (bZIP) TF \\
\hline PHD & 34 & IPR00I965 & $\mathrm{P}$ & Zn-finger like, PHD-finger \\
\hline WRKY family & & IPR003657 & D & DNA-binding WRKY \\
\hline WRKY & 29 & & & \\
\hline LLR WRKY & $\mathbf{I}$ & IPRO0I6II & & Leu-rich repeat \\
\hline ABI3/VPI & 29 & IPR003340 & D & TF B3 \\
\hline NAC & 29 & IPR00344 I & D & No apical meristem (NAM) protein \\
\hline $\mathrm{C}_{3} \mathrm{H}$-type I $(\mathrm{Zn})$ & 27 & IPR00057I & $\mathrm{D}$ & Zn-finger, C-x8-C-x5-C-x3-H type \\
\hline ARF & 23 & IPR003340, IPRO I 0525 , IPROI I 525 & D & \\
\hline JUMONJI & 20 & IPR003347 & $\mathrm{D}$ & TF jumonji, jmjC \\
\hline GRAS & 19 & IPR005202 & $\mathbf{P}$ & GRAS TF \\
\hline HMG & 15 & IPR000637 & $\mathrm{D}$ & HMG-I and HMG-Y, DNA binding \\
\hline AS2 & 14 & IPR004883 & $\mathrm{P}$ & Lateral organ boundaries \\
\hline \multicolumn{5}{|l|}{$\mathrm{C}_{2} \mathrm{C}_{2}(\mathrm{Zn})$} \\
\hline Dof & 13 & IPR00385 I & D & Zn-finger, Dof type \\
\hline GATA & 7 & IPR000679 & $\mathrm{D}$ & Zn-finger, GATA type \\
\hline CO-like & 6 & IPR0003 I5 & D & Zn-finger, B-box \\
\hline YABBY & 5 & IPR006780 & D & YABBY protein \\
\hline CCAAT-HAP3 type & 12 & IPR003958 & $\mathrm{D}$ & TF CBF/NF-Y/archaeal histone \\
\hline GRF & 8 & IPROI 0666 & D & Zn-finger, GRF type \\
\hline SBP & 8 & IPR004333 & D & SBP \\
\hline EIL & 7 & IPR006957 & D & Ethylene insensitive 3 \\
\hline LIM & 7 & IPR00I78I & $P$ & Zn-binding protein, LIM \\
\hline SNF2 & 6 & IPR000330 & $\mathrm{D}$ & SNF2 family N-terminal domain \\
\hline E2F/DP & 5 & IPR0033I6 & $\mathrm{D}$ & TF E2F/dimerisation partner (TDP) \\
\hline TCP & 5 & IPR005333 & D & TCP TF \\
\hline FHA & 5 & IPR000253 & D & Forkhead-associated \\
\hline ARID & 4 & IPR00I606 & $\mathrm{D}$ & AT-rich interaction region \\
\hline $\mathrm{HSF}$ & 4 & IPR000232 & $\mathrm{D}$ & Heat shock factor (HSF)-type, DNA binding \\
\hline AUX/IAA & 3 & IPR0033II & D & AUX/IAA protein \\
\hline SRS & 3 & IPR0065 I0 & D & Zn-finger, LRPI type \\
\hline TUB & 3 & IPR000007 & $\mathrm{D}$ & Tubby \\
\hline ZIM & 3 & IPR0I0399 & $\mathrm{D}$ & ZIM \\
\hline DDT & 3 & IPR004022 & $\mathrm{D}$ & DDT \\
\hline ZF-HD & 2 & IPR006455 & D & Homeobox domain, ZF-HD class \\
\hline MBF I & 2 & IPR00I 387 & D & Helix-turn-helix type 3 \\
\hline SIFa-like & 2 & IPR006779 & D & DNA binding protein SIFA \\
\hline CAMTA & 2 & IPR005559 & D & CG-I \\
\hline LFY & I & IPRO02910 & D & Floricaula/leafy protein \\
\hline Nin-like & I & IPR003035 & D & Plant regulator RWP-RK \\
\hline TAZ & i & IPR000I 97 & $\mathbf{P}$ & Zn-finger, TAZ-type \\
\hline
\end{tabular}

Potentially novel plant TFs and transcriptional regulators

\begin{tabular}{lcccc}
\hline $\mathrm{CCHC}(\mathrm{Zn})$ & 112 & IPR00I878 & NA & Zn-finger, CCHC-type \\
$\mathrm{RR}$ & 16 & IPR00I789, IPR0II006 & RD & Response regulator receiver
\end{tabular}


Table I: Classification of putative transcription factors of Medicago into families and sub-families (Continued)

\begin{tabular}{|c|c|c|c|c|}
\hline DHHC (Zn) & 14 & IPR001594 & $\mathrm{D}$ or $\mathrm{P}$ & Zn-finger, DHHC-type \\
\hline \multicolumn{5}{|l|}{ HTH } \\
\hline FIS & 11 & IPR002I97 & $\mathrm{D}$ & Helix-turn-helix, Fis-type \\
\hline AraC & 2 & IPR000005 & $\mathrm{D}$ & Helix-turn-helix, AraC type \\
\hline BTB/POZ & 7 & IPR0002I0 & $P$ & BTB \\
\hline TTF-type (Zn) & 6 & IPR006580 & $\mathrm{D}$ & Zn-finger, TTF-type \\
\hline $\mathrm{BD}$ & 6 & IPR00| 487 & $P$ & Bromodomain \\
\hline Lambda-DB & 3 & IPR0I0982 & $\mathrm{D}$ & Lambda_DNA_bd \\
\hline TrpR & 3 & IPR0I092I & $\mathrm{D}$ & Trp repressor/replication initiator \\
\hline TPR & 3 & IPR00I 440 & $P$ & Tetratricopeptide TPR_I \\
\hline KRAB-box & 2 & IPR00I909 & $P$ & KRAB box \\
\hline NRs & 2 & IPR008946 & LBD & Steroid nuclear receptor, ligand binding \\
\hline $\mathrm{R} 3 \mathrm{H}$ & 2 & IPR00I374 & NA & Single-stranded nucleic acid binding $\mathrm{R} 3 \mathrm{H}$ \\
\hline YEATS & 2 & IPR005033 & TA & YEATS \\
\hline Ul-type (Zn) & 2 & IPR003604 & NA & Zn-finger, UI-type \\
\hline A20-like & 2 & IPR002653 & $P$ & Zn-finger, A20-type \\
\hline Euk_TF & I & IPR0089I7 & $\mathrm{D}$ & Euk_TF, DNA binding \\
\hline$N G \bar{N}$ & I & IPR006645 & $\mathrm{D}$ & NGN \\
\hline p53-like & I & IPR008967 & $\mathrm{D}$ & p53-like TF, DNA binding \\
\hline SSB protein & I & IPR0II 344 & $\mathrm{D}$ & Single-strand binding protein \\
\hline ssDB TR & I & IPR009044 & $\mathrm{D}$ & Single-strand DNA binding transcriptional regulator \\
\hline TCoApI5 & I & IPR003I73 & $\mathrm{D}$ & Transcriptional coactivator pl5 \\
\hline BED-type (Zn) & I & IPR003656 & $\mathrm{D}$ & Zn-finger, BED-type predicted \\
\hline TCOA & I & IPR009255 & TA & Transcriptional coactivation \\
\hline $\mathrm{Tc} / \mathrm{PD}$ & I & IPR00I533 & TA & Transcriptional coactivator \\
\hline
\end{tabular}

IMGAG (International Medicago Gene Annotation Group)-proteins were classified as putative TFs if they contained characteristic DNA-binding or other characteristic TF domains and if annotations of matching proteins obtained by BLAST searches were consistent with such a classification. TF families previously identified in plants are presented in the first part of the table while potentially novel plant TF families, which were identified by the presence of domains associated with TFs and other transcriptional regulators outside the plant kingdom, are presented in the latter part of the table. $D=$ DNA binding domain; $P=$ protein-protein interaction domain; NA = nucleic acid (DNA and RNA) binding domain; RD = receiver domain; LBD = ligand binding; transcriptional co-activator. Plant-specific TF families and sub-families are indicated in bold (according to [12])

been inevitable if we chose to use ESTs in addition to genomic sequences to identify Medicago TFs.

\section{PCR primer design}

To ensure maximum specificity and efficiency during PCR amplification of TF cDNA under a standard set of reaction conditions, a stringent set of criteria was used for primer design. This included predicted melting temperatures $\left(T_{\mathrm{m}}\right)$ of $58^{\circ} \mathrm{C}$ to $61^{\circ} \mathrm{C}$, limited self-complementarity and poly-X, and PCR amplicon lengths of 100-150 base pairs (bp). Secondary hits were minimized by aligning primer candidates to all known Medicago sequences via WUBLAST [28] and eliminating primer pairs with multiple potential hits.

\section{PCR primer testing: gene-specificity and amplification efficiency}

PCR primers were tested on Medicago cDNA free of genomic DNA contamination as follows. First, total RNA was extracted from various organs using Trizol reagent (Invitrogen $\mathrm{GmbH}$, Karlsruhe, Germany), which yielded high quality RNA as judged by gel electrophoresis and by Agilent 2100 BioAnalyser using RNA 6000 Nano Chips (Agilient Technologies, Waldbronn, Germany). Typical RNA yields ranged from $0.5-1.0 \mu \mathrm{g}$ RNA/mg fresh mass for nodules and leaves, respectively. Isolated RNA was treated with DNAse I (Ambion, product number 1907) to remove all contaminating genomic DNA, and this was always confirmed by PCR using primers to non-coding regions of the Ubiquitin gene (TC102473; AC13782819.4). After inactivation of DNAse I, RNA was reverse transcribed using SuperScript III reverse transcriptase (Invitrogen GmbH, Karlsruhe, Germany) and oligo-dT ${ }_{12-18}$ to prime the reaction.

Specificity of PCR primers was assessed in three ways: by melting curve analysis of PCR reaction products; by separating the products of all reactions via electrophoresis in $3 \%$ agarose gels; and by sequencing a sub-set of PCR reaction products (Figure 1). 94.5\% (998/1045) of primer pairs gave unique PCR products of the expected size. Only $3.3 \%(34 / 1045)$ of primer pairs yielded no product and $2.2 \%$ (23/1045) gave non-specific products. (see Additional file 1). Sequencing was performed on 178 randomly-chosen PCR products amplified from a 1:1 mixture of leaf and root cDNA. In the vast majority of cases (92.7\% or $165 / 178)$, the sequence of the PCR product was identical to that of the intended target gene. In $5.1 \%$ of cases, the amplicon sequence matched multiple related genes, including the target gene, while in only $2.2 \%$ of cases the amplicon sequence did not match the target gene sequence. 

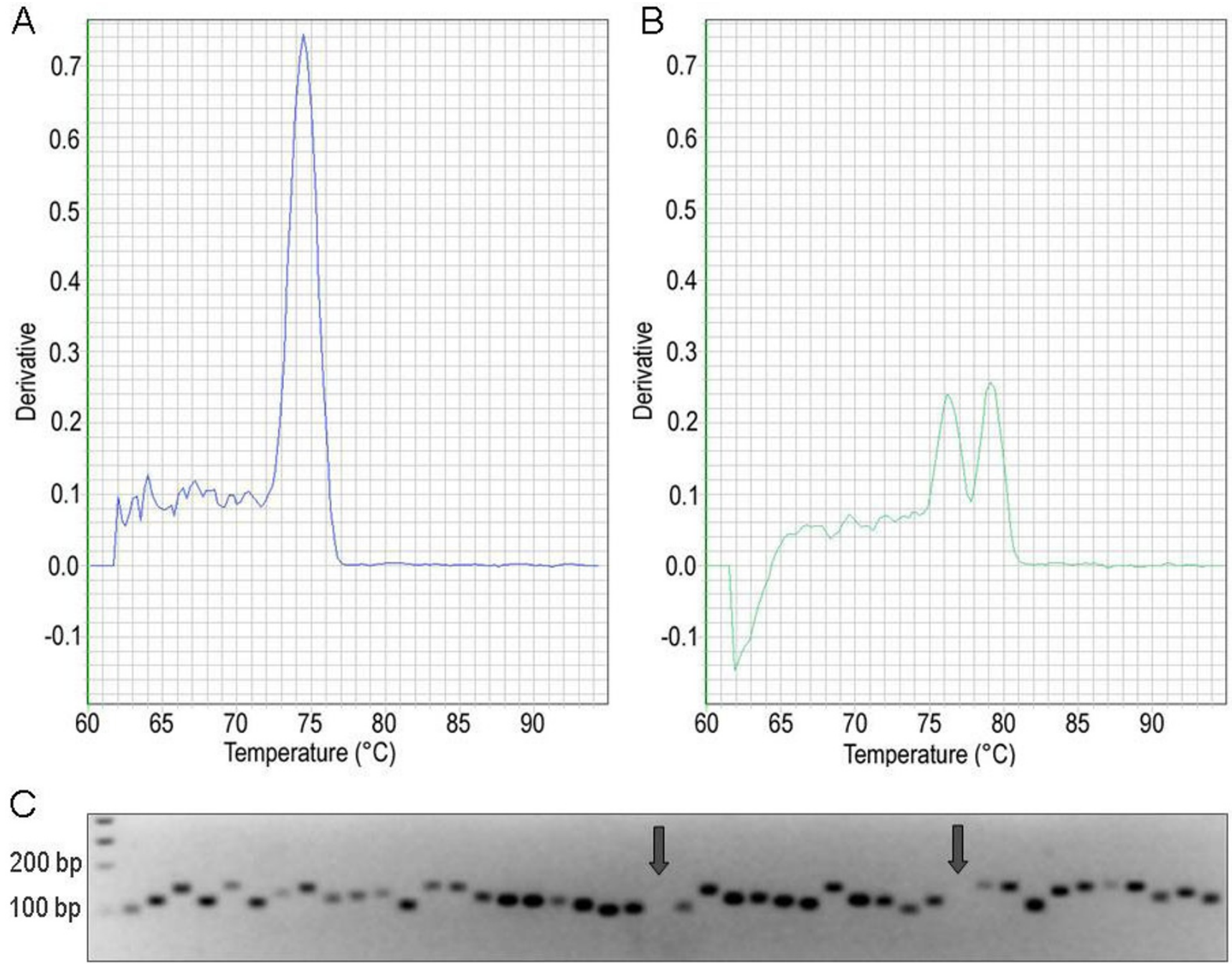

Figure I

Specificity of transcription factor PCR primers. Specificity was confirmed by dissociation curves with a single peak (A) while double peaks (B) indicated off-target ampification. The derivative of fluorescence intensity is shown on the $y$-axis. Separation of PCR products on 3\% (v/w) agarose gels following electrophoresis (C) confirmed the presence of unique amplicons of the expected size for most reactions. Few reactions yielded no products (indicated by arrow).

Ideally, PCR results in an exact doubling of the amount of dsDNA after each temperature cycle. In practice, however, this is generally not the case because the reactions are less than $100 \%$ efficient. Primer sequences can affect PCR efficiency, so we determined the efficiency of each TF primer pair from amplification plots, using LinRegPCR software [31]. First, the correlation coefficient derived from linear regression analysis of each amplification plot (e.g. see Figure 2) was used to assess the 'quality' of each reaction, and all reactions with an $\mathrm{R}^{2}<0.990$ were excluded from further analysis (10.6\% of reactions). Next, average PCR efficiencies (E) were computed for each individual primer pair across all analyzed samples. 53.4\% (558 TF genes) displayed PCR efficiencies greater than 0.80 , while $39.7 \%$
(415 TF genes) had efficiencies between 0.51-0.80. Only $2.6 \%$ ( 27 TF genes) had mean E values below 0.4; these all yielded $\mathrm{R}^{2}<0.99$ in LinRegPCR analysis and mostly represented reactions that lacked detectable fragment amplification $\left(\mathrm{C}_{\mathrm{T}}>40\right)$ or that generated unspecific PCR products (Figure 2; see Additional file 1). A similar range of PCR efficiencies were determined for Arabidopsis and rice TF primers previously $[19,20]$.

\section{Selection of reference genes}

Reference genes with stable expression/transcript levels throughout development and in the face of environmental challenge are crucial for the normalization of expression data of other genes. Potentially useful reference genes 

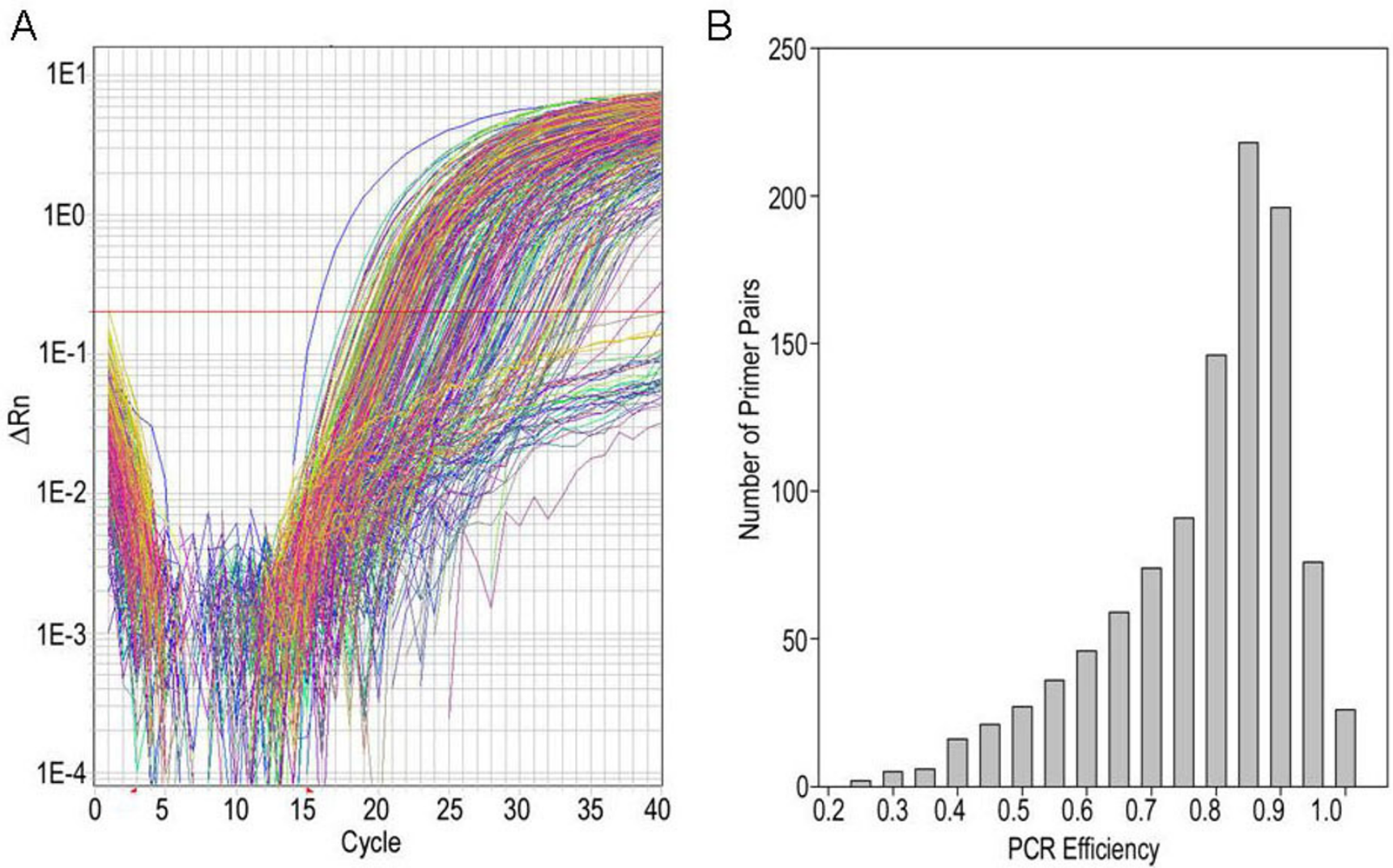

Figure 2

Amplification efficiency of transcription factor-specific primer pairs. Typical real-time RT-PCR amplification plots of 384 TF genes (left) and distribution of PCR efficiencies for all I045 TF primer pairs (right).

were chosen based on published data for Medicago (e.g. Msc27 [32]) and Arabidopsis thaliana [33]. The closest Medicago homologues of Arabidopsis genes were identified by BlastN [29]. Gene-specific primer pairs for the genes encoding elongation factor $1 \alpha$ (EST317575), glyceralaldehyde-3-phosphate dehydrogenase (MtC00030_GC; CT573421_3.4), $\beta$-tubulin (TC106341), Pentatricopeptide repeat protein (TC96273), actin2 (TC107326; AC137836_27.5), Ubiquitin (TC102473; AC13782819.4), Helicase (CB892427), and the genes PDF2 (TC107161), UPL7 (TC111218), PTB (TC111751), UBC (AW686873), bHLH (CX538576), and UBC9 (TC106312) were designed using the criteria described above (Table 2). The specificity of PCR primers was tested using 18 first-strand cDNAs from six different organs of Medicago (three biological replicates each). All primer pairs produced a single PCR product of the expected size, as shown by gel electrophoresis and unique dissociation curves generated by the PCR machine after 40 cycles (Figure 3). To determine which reference genes were best suited for transcript normalisation, we used the software geNORM [34], which uses pair-wise comparison and geometric averaging across a matrix of biological samples to determine gene expression stability $(\mathrm{M} ;[35])$. The genes PDF2, PPRep, Ubiquitin, and PTB had the lowest M (greatest transcript stability) and, therefore, were judged to be the best reference genes for this diverse set of developmental samples (Figure 4; Table 2).

\section{Identification of organ-enhanced TFs of Medicago}

To get an overview of TF gene expression in Medicago truncatula and to identify TFs induced in specific organs, we used the real-time RT-PCR platform described above. Transcript profiling was performed on six different organs of Medicago (leaves, stems, flowers, pods, roots, and nodules) with three independent biological replicates for each (see Additional file 2). The fraction of genes for which transcripts were detected within 40 cycles ranged from $77.2 \%$ in leaves to $90.8 \%$ in pods. Transcripts from nearly all putative TF genes $(96.8 \%$ or $1011 / 1045)$ were detected in at least one organ. Genes were called detected if they were expressed in at least two biological replicates with a $\mathrm{C}_{\mathrm{T}}<40$. Approximately half of all TF genes exhibited differential expression during plant development, based on significant differences $(\mathrm{p} \leq 0.05)$ in transcript levels between organs. Few TF genes $(1.19 \%$ or $12 / 1011)$ were 
Table 2: Medicago reference genes and primers for qRT-PCR

\begin{tabular}{|c|c|c|c|c|c|c|}
\hline Gene Name & TC & $\begin{array}{l}\text { Accession } \\
\text { Number }\end{array}$ & Forward/Reverse Primer (5'-3') & $\begin{array}{c}\text { PCR } \\
\text { Product } \\
\text { Size (bp) }\end{array}$ & $\begin{array}{c}\text { PCR } \\
\text { efficiency } \\
\text { (E) }\end{array}$ & $\mathbf{R}^{2}$ \\
\hline$\beta$ Tubulin & TCI0634I & $\mathrm{N}$ & $\begin{array}{l}\text { TTTGCTCCTCTTACATCCCGTG / } \\
\text { GCAGCACACATCATGTTTTTGG }\end{array}$ & 100 & 1.08 & $\begin{array}{c}1.0 \\
0\end{array}$ \\
\hline PPRrep & TC96273 & $\mathrm{N}$ & $\begin{array}{l}\text { GGAAAACTGGAGGATGCACGTA / } \\
\text { ACAAGCCCTCGACACAAAACC }\end{array}$ & 100 & 0.93 & $\begin{array}{c}1.0 \\
0\end{array}$ \\
\hline PDF 2 & $\mathrm{TC} 107161$ & $\mathrm{~N}$ & $\begin{array}{c}\text { GTGTTTTGCTTCCGCCGTT / } \\
\text { CCAAATCTTGCTCCCTCATCTG }\end{array}$ & 100 & 0.99 & $\begin{array}{c}1.0 \\
0\end{array}$ \\
\hline bHLH & CX538576 & $\mathrm{N}$ & $\begin{array}{l}\text { TAGCGAGTACCATGATGCCAGA / } \\
\text { GCGCCTCTTTTGTTTTCAGC }\end{array}$ & 100 & 0.89 & $\begin{array}{c}1.0 \\
0\end{array}$ \\
\hline UBC & AW686873 & $\mathrm{N}$ & $\begin{array}{l}\text { CTGACAGCCCACTGAATTGTGA / } \\
\text { TTTTGGCATTGCTGCAAGC }\end{array}$ & 100 & 0.96 & $\begin{array}{c}1.0 \\
0\end{array}$ \\
\hline PTB & TCIII75I & $\mathrm{N}$ & $\begin{array}{l}\text { CGCCTTGTCAGCATTGATGTC / } \\
\text { TGAACCAGTGCCTGGAATCCT }\end{array}$ & 100 & 0.85 & $\begin{array}{c}1.0 \\
0\end{array}$ \\
\hline Ubiquitin & TCI02473 & ACI37828_19.4 & $\begin{array}{l}\text { GCAGATAGACACGCTGGGA / } \\
\text { AACTCTTGGGCAGGCAATAA }\end{array}$ & 100 & 0.95 & $\begin{array}{c}1.0 \\
0\end{array}$ \\
\hline UBC9 & $\mathrm{TC} 106312$ & ACI37602_2.4 & $\begin{array}{l}\text { GGTTGATTGCTCTTCTCTCCCC / } \\
\text { AAGTGATTGCTCGTCCAACCC }\end{array}$ & 100 & 1.13 & $\begin{array}{c}0.9 \\
9\end{array}$ \\
\hline Helicase & CB892427 & $\mathrm{N}$ & $\begin{array}{l}\text { GTACGAGGTCGGTGCTCTTGAA / } \\
\text { GCAACCGAAAATTGCACCATAC }\end{array}$ & 100 & 0.91 & $\begin{array}{c}1.0 \\
0\end{array}$ \\
\hline ELFI $\alpha$ & EST3I7575 & $\mathrm{N}$ & $\begin{array}{l}\text { GACAAGCGTGTGATCGAGAGATT / } \\
\text { TTTCACGCTCAGCCTTAAGCT }\end{array}$ & 100 & 0.68 & $\begin{array}{c}0.9 \\
8\end{array}$ \\
\hline UPL7 & $\mathrm{TCIII} 1218$ & $N$ & $\begin{array}{l}\text { CCAGTTGTTCTCGTGGTCCATT / } \\
\text { CCTCCAATTGTCGCCCAAA }\end{array}$ & 100 & 0.93 & $\begin{array}{c}1.0 \\
0\end{array}$ \\
\hline GAPDH & MtC00030_GC & CT57342I_3.4 & $\begin{array}{l}\text { TGCCTACCGTCGATGTTTCAGT / } \\
\text { TTGCCCTCTGATTCCTCCTTG }\end{array}$ & 100 & 1.04 & $\begin{array}{c}0.9 \\
9\end{array}$ \\
\hline Actin2 & TCI07326 & ACI37836_27.5 & $\begin{array}{l}\text { TCAATGTGCCTGCCATGTATGT / } \\
\text { ACTCACACCGTCACCAGAATCC }\end{array}$ & 100 & 1.12 & $\begin{array}{c}0.9 \\
9\end{array}$ \\
\hline $\mathrm{MSC} 27$ & X63872 (M. sativa) & $\mathrm{N}$ & $\begin{array}{l}\text { GTTGAAGTAGACATTGGTGCTAACG / } \\
\text { AGCTGAGTCATCAACACCCTCAT }\end{array}$ & 100 & 0.76 & $\begin{array}{c}0.9 \\
9\end{array}$ \\
\hline
\end{tabular}

Mean PCR efficiency $(E)$ was determined from three biological replicates of each of six organs, using LinRegPCR [3I], which also yielded mean $\mathrm{R}^{2}$. $\mathrm{N}$, no corresponding GenBank accession number.

expressed exclusively in vegetative organs (leaves, stems, roots or nodules), and even fewer $(0.5 \%$ or $5 / 1011)$ were expressed only in reproductive organs (flowers or pods). A relatively small number of TF genes exhibited greater than ten-fold ratios in expression level in one organ compared to any other organ (Table 3 ). For comparison, we have included gene expression ratios derived from Affymetrix array data from the same RNA samples. While there is reasonable qualitative agreement between gene expression ratios obtained using the two methods, the lack of quantitative agreement is likely due to the limited sensitivity and low signal to noise ratio near the detection limit of Affymetrix arrays [19]. The genes listed in Table 3 may control development and/or differentiation in Medicago and are interesting targets for future research.

\section{Conclusion}

We have established a flexible platform for high-throughput qRT-PCR analysis of Medicago TF gene expression that is based on gene-specific primers arrayed in 384-well plates and SYBR ${ }^{\circledast}$ Green detection of gene-specific PCR amplicons. Currently, the platform has primer pairs for $1045 \mathrm{TF}$ genes and we have plans to extend this to all pre- dicted Medicago TF genes as genome sequencing progresses. At this stage, the resource has been utilized by several groups in Europe, Australia, and the USA, and we expect it will become the 'gold-standard' for TF transcript profiling in Medicago truncatula.

\section{Methods}

Plant material and growth conditions

Medicago truncatula $\mathrm{cv}$. Jemalong, line A17 wild type plants were vernalized for 3 days in the dark at $4{ }^{\circ} \mathrm{C}$ on sterile, wet filter paper. Germinated seedlings were transferred to pots containing Turface (BWI Texarcana, Texarcana, TX). Plants were grown in growth chambers under a $16 \mathrm{~h}$ day and $8 \mathrm{~h}$ night regime, at $200 \mu \mathrm{E}$ light intensity, $24^{\circ} \mathrm{C}$ and $40 \%$ relative humidity.

Vegetative organs (leaves, stems, roots, and nodules) were harvested 28 days after planting. Leaf material did not include petioles and stems did not include buds. Roots consisted of the entire root system with laterals. Several plants grown at the same time were pooled for each of the three biological replicates. Biological replicates were planted on separate days. Nodules were harvested from 

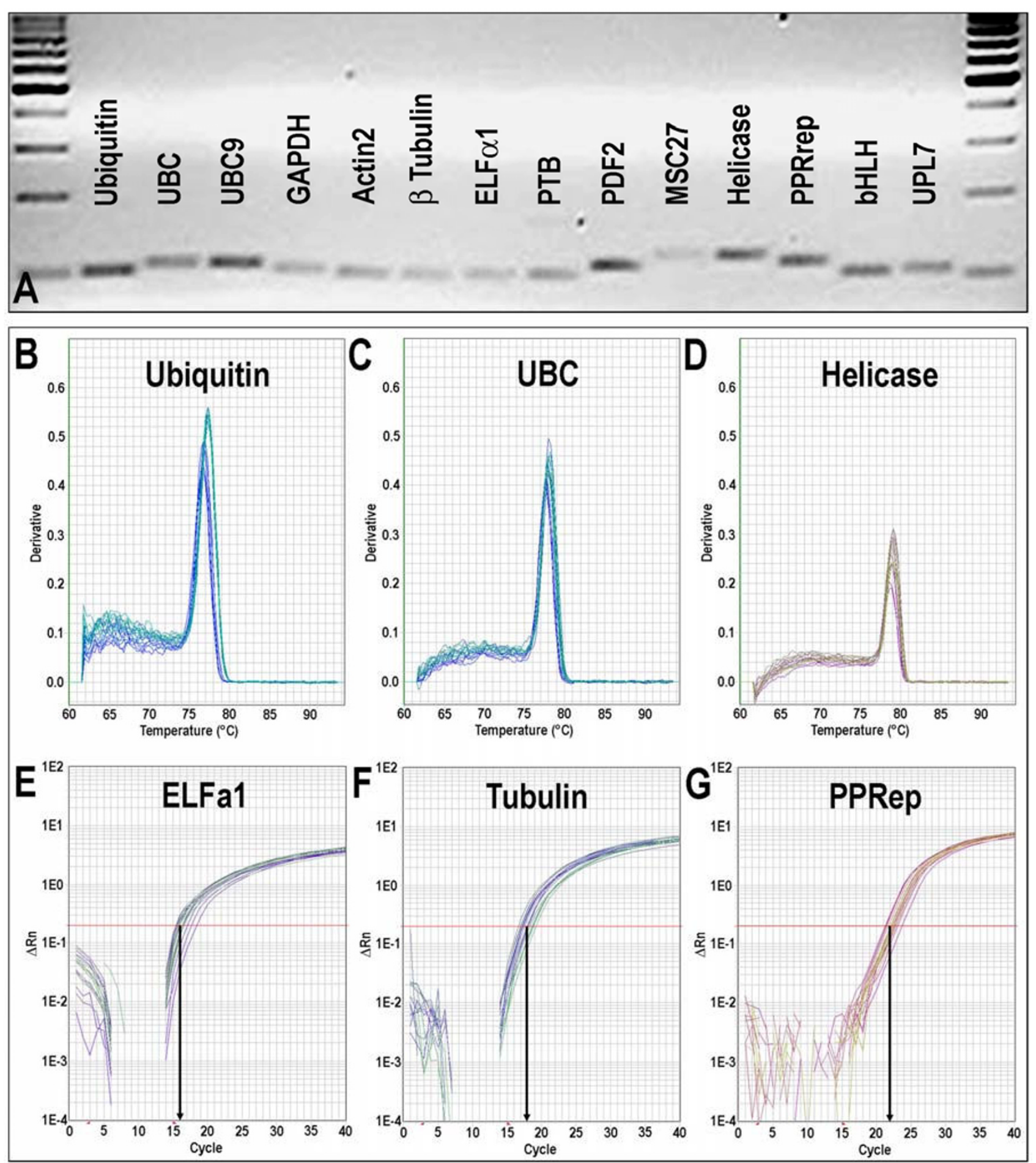

\section{Figure 3}

Specificity, efficiency, and reproducibility of PCR primers designed to amplify reference gene transcripts. Specificity of primers was confirmed by the presence of unique amplicons of the expected size following electrophoresis on $3 \%$ ( $v /$ w) agarose gels $(A)$ and by dissociation curves with a single peak (B to D). Typical real-time RT-PCR amplification plots of three reference gene transcripts ( $E$ to $G$ ). 


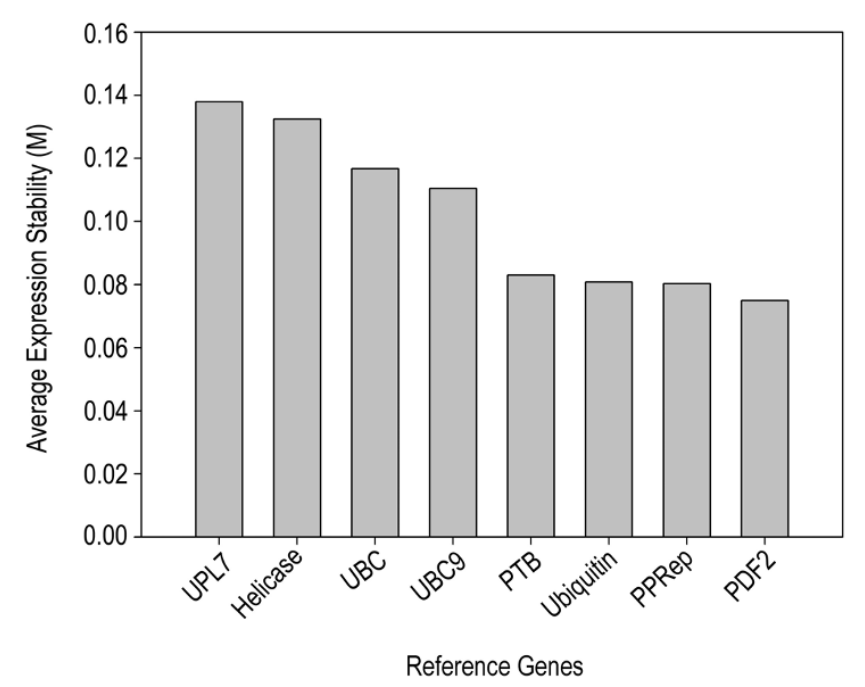

Figure 4

Ranking of 8 reference genes in $M$. truncatula. Transcript levels of all 8 genes were measured by qRT-PCR, using 18 independent cDNA preparations from six different organs with three replicate measurements of each cDNA preparation. A low value for the average expression stability $M$, as calculated by geNORM software, indicates more stable expression throughout the various organs.

plants inoculated with Sinorhizobium meliloti strain 1021 one and seven days after sowing. Reproductive organs were harvested from plants that were vernalized for two weeks to decrease the time to flowering. Flowers were harvested on the day of opening. Pods were harvested from 1 to 21 days after the appearance of the floral bud to cover a wide range of developmental stages. Harvested plant material was frozen in liquid nitrogen before storage at $80^{\circ} \mathrm{C}$.

\section{RNA isolation and CDNA synthesis}

Total RNA was extracted using Trizol reagent [36], following the manufacturer's instructions (Invitrogen $\mathrm{GmbH}$, Karlsruhe, Germany). RNA was quantified using a Nanodrop Spectrophotometer ND-100 (NanoDrop Technologies, Wilington, DE). Sixty $\mu$ g of total RNA were digested with RNase free DNase1 (Ambion Inc., Houston, TX), according to manufacturer's protocol. RNA integrity was checked using an Agilent 2100 BioAnalyser and RNA 6000 Nano Chips (Agilient Technologies, Waldbronn, Germany), and by electrophoresis on a $3 \%(\mathrm{v} / \mathrm{w})$ agarose gel before and after DNase I treatment. The absence of contaminating genomic DNA after DNase I treatment was verified by PCR analysis, using primer pairs designed to amplify a 107 bp genomic fragment of the control gene, Ubiquitin (TC102473intronF, 5'-GTCCTCTAAGGTTTAATGAACCGG-3'; TC102473intronR, 5'-GAAAGACACAGCCAAGTTGCAC-3').
First-strand complementary DNA was synthesized by priming with oligo-dT ${ }_{12-18}$ (Qiagen, Hilden, Germany), using SuperScript III reverse transcriptase (Invitrogen $\mathrm{GmbH}$, Karlsruhe, Germany) following the instructions of the provider. To assess cDNA synthesis efficiency, qPCR was used to amplify segments in the 5' and 3 ' regions of Ubiquitin cDNA approx. 1600 and 400 bp from the 3 '-end, respectively (primers: TC102473_5'F, 5'-TTGGAGACGGATTCCATTGCT-3'; TC102473_5'R, 5'-GCCAATTCCTTCCCTTCGAA-3; TC102473_3'F, 5'GGCCCTAGAACATTTCCTGTGG-3'; and TC102473_3'R, 5'-TTGGCAACCAAAATGTTCCC-3'). If $\Delta \mathrm{Ct}$ (Ct3'-Ct5') < 2 , then cDNA synthesis efficiency was judged to be satisfactory, and the cDNA was considered suitable for qRTPCR analysis.

\section{PCR primer design}

The primer design pipeline was implemented in objectoriented PERL modules supported by a MySQL relational database. Primers iterated through three phases before approval: design, specificity, and selection.

The design phase interrogated TF genes with a sliding window 250 bp across that stepped 50 bp along the entire target sequence, generating primer candidates at each window. Experimental conditions, as outlined in the Results section above, were enforced by the following MIT Primer3 parameters: PRIMER_MIN_TM 58, PRIMER_OPT_TM 60, PRIMER_MAX_TM 61, PRIMER_SELF_ANY 6, PRIMER_SELF_END 2, PRIMER_MAX_POLY_X 3, and PRIMER_PRODUCT_SIZE_RANGE '100-150' [37]. The specificity phase aligned primer candidates via WU-Blast to a database of all known Medicago sequences. The selection phase sorted primer candidates by the number of possible secondary hits, self-complementarity, and poly-X characteristics. Secondary hits were defined as specificity alignments that contained at least one of the terminal ends of the primer and achieved $80 \%$ or greater identity over the length of the primer. The sequences of each primer pair are given in Supplementary Material (see Additional file 1).

\section{Real-time PCR conditions and analysis}

PCR reactions were carried out in an ABI PRISM ${ }^{\circledast} 7900$ HT Sequence Detection System (Applied Biosystems, Foster City, CA, USA). SYBR ${ }^{\circledast}$ Green was used to quantify dsDNA synthesis. Reactions ( $5 \mu$ l total volume) were performed in an optical 384-well plate containing $2.5 \mu \mathrm{l} 2 \times \mathrm{SYBR}^{\circledR}$ Green Power Master Mix reagent (Applied Biosystems, Warringen, UK), $5 \mathrm{ng}$ cDNA and $200 \mathrm{~nm}$ of each gene-specific primer. Primer pairs were aliquoted using a pipetting robot (Evolution P3 liquid handling system, Perkin Elmer, MA, USA) to minimize pipetting errors. cDNA was aliquoted as a master mix of CDNA and $2 \times \mathrm{SYBR}^{\circledR}$ Green 
Table 3: Organ-enhanced TF genes

A Root-enhanced TF genes identified by real-time RT-PCR

\begin{tabular}{|c|c|c|c|c|c|c|c|c|c|c|c|}
\hline \multirow[b]{2}{*}{ Accession Number } & \multicolumn{5}{|c|}{ Real-time RT-PCR Expression Ratio } & \multicolumn{5}{|c|}{ Affymetrix Expression Ratio } & \multirow[b]{2}{*}{ Affymetrix Chip ID } \\
\hline & $R / L$ & $\mathbf{R} / \mathbf{S}$ & $\mathbf{R} / \mathbf{F}$ & $\mathbf{R} / \mathbf{P}$ & $\mathbf{R} / \mathbf{N}$ & $R / L$ & $\mathbf{R} / \mathbf{S}$ & $\mathbf{R} / \mathbf{F}$ & $\mathbf{R} / \mathbf{P}$ & $\mathbf{R} / \mathbf{N}$ & \\
\hline ACI4072I_I2.I & 121.5 & 320.1 & 1623.4 & 2676.5 & 64.4 & $161.2^{b}$ & $144.5^{b}$ & $219.2^{b}$ & $158.1^{b}$ & 99.9 & Mtr.50075.I.SI_s_at \\
\hline ACI35I0I_25.I & 312.2 & 438.0 & 291.6 & 787.0 & 61.3 & $\mathrm{n}$ & $\mathrm{n}$ & $\mathrm{n}$ & $\mathrm{n}$ & $\mathrm{n}$ & $n$ \\
\hline ACl4072I_14.I & 1204.9 & 751.2 & 956.6 & 6296.6 & 32.6 & $\mathrm{n}$ & $\mathrm{n}$ & $\mathrm{n}$ & $\mathrm{n}$ & $\mathrm{n}$ & $\mathrm{n}$ \\
\hline ACI4003I_3.I & 275.4 & 1157.3 & 923.4 & $258916.9 \mathrm{a}$ & 31.1 & 0.4 & 0.7 & 0.8 & 0.9 & 2.2 & Mtr.47227.I.SI_s_at \\
\hline ACl4072I_I3.I & $39.9^{\mathrm{a}}$ & 179.8 & 614.8 & $935.1^{a}$ & 26.5 & 35.9 & $48.1^{b}$ & 41.2 & $44.2^{b}$ & 39.5 & Mtr.50074.I.SI_at \\
\hline ACI4003I_7.I & $360.2^{\mathrm{a}}$ & 830.6 & $1542^{\mathrm{a}}$ & 6868.8 & 19.7 & $0.7 \mathrm{~b}$ & $\mathrm{I}^{\mathrm{b}}$ & $1.1^{\mathrm{b}}$ & $\mathrm{I}^{\mathrm{b}}$ & $0.9 b$ & Mtr.47229.I.SI_at \\
\hline ACI46574_6.I & 1095.7 & $11.9^{a}$ & 48.8 & 51.8 & 88.8 & $1.2^{\mathrm{b}}$ & $1.1^{\mathrm{b}}$ & $1.3^{\mathrm{b}}$ & $1.1^{b}$ & $1.2^{\mathrm{b}}$ & Mtr.4078I.I.SI_s_at \\
\hline ACI25478_13.7 & 1117.4 & 7008.0 & $3264.9 \mathrm{a}$ & 7256.6 & 11.6 & $211.5^{b}$ & $248.8^{b}$ & $296.4^{b}$ & $228.7 \mathrm{~b}$ & 45.3 & Mtr.154|6.I.SI_at \\
\hline ACI25478_7.2 & 1052.3 & 503.3 & $938.4^{a}$ & 2754.5 & 11.2 & $\mathrm{n}$ & $\mathrm{n}$ & $\mathrm{n}$ & $\mathrm{n}$ & $\mathrm{n}$ & $n$ \\
\hline ACI22726_2I.III & 50.0 & 48.0 & 20943.9 & 2658.6 & 10.4 & $74.3^{b}$ & $76.4^{\mathrm{b}}$ & $72.8^{\mathrm{b}}$ & $82.8^{\mathrm{b}}$ & 26.6 & Mtr.15568.I.SI_s_at \\
\hline
\end{tabular}

B Nodule-enhanced TF genes identified by real-time RT-PCR

Real-time RT-PCR Expression Ratio

Affymetrix Expression Ratio

\begin{tabular}{|c|c|c|c|c|c|c|c|c|c|c|c|}
\hline Accession Number & N/L & N/S & N/F & N/P & N/R & N/L & N/S & N/F & N/P & N/R & Affymetrix Chip ID \\
\hline ACI488I6_3.2 & 9966.7 & 1826.2 & 6262.9 & 21709.1 & 662.7 & $434.6^{\mathrm{b}}$ & $516.8^{\mathrm{b}}$ & $455^{b}$ & $521.7^{b}$ & $551.4^{b}$ & Mtr.I4503.I.SI_at \\
\hline ACI47774_3.2 & $55.2^{\mathrm{a}}$ & 466.7 & 726.3 & 881.2 & 498.5 & $17.7^{\mathrm{b}}$ & $16^{b}$ & $17.8^{\mathrm{b}}$ & $19.1^{6}$ & $16.1^{b}$ & Mtr.19554.I.SI_at \\
\hline ACI38056_33.24I & 43.9 & 93.2 & 18.3 & 17.3 & 13.1 & $0.9 b$ & $0.8^{\mathrm{b}}$ & $0.8^{\mathrm{b}}$ & $1.1^{b}$ & $\mathrm{I} . \mathrm{I}^{\mathrm{b}}$ & Mtr.I7993.I.SI_at \\
\hline ACI24214_39.2 & 121.8 & 92.1 & 44.8 & 64.9 & 10.5 & $\mathrm{n}$ & $\mathrm{n}$ & $\mathrm{n}$ & $\mathrm{n}$ & $\mathrm{n}$ & $\mathrm{n}$ \\
\hline
\end{tabular}

C Pod-enhanced TF genes identified by real-time RT-PCR

\begin{tabular}{|c|c|c|c|c|c|c|c|c|c|c|c|}
\hline \multirow[b]{2}{*}{ Accession Number } & \multicolumn{5}{|c|}{ Real-time RT-PCR Expression Ratio } & \multicolumn{5}{|c|}{ Affymetrix Expression Ratio } & \multirow[b]{2}{*}{ Affymetrix Chip ID } \\
\hline & P/L & $\mathbf{P} / \mathbf{S}$ & $\mathbf{P} / \mathbf{F}$ & $\mathbf{P} / \mathbf{N}$ & $\mathbf{P} / \mathbf{R}$ & P/L & $\mathbf{P} / \mathbf{S}$ & $\mathbf{P} / \mathbf{F}$ & $\mathbf{P} / \mathbf{N}$ & $\mathbf{P} / \mathbf{R}$ & \\
\hline $\mathrm{ACl} 43340 \_4.7$ & 154.1 & 44.8 & 173.3 & $180.3^{a}$ & 407.3 & $1.6^{b}$ & $1.8^{\mathrm{b}}$ & $1.7^{\mathrm{b}}$ & $1.7 \mathrm{~b}$ & $1.7^{\mathrm{b}}$ & Mtr.|793I.I.SI_at \\
\hline
\end{tabular}

D Flower-enhanced TF genes identified by real-time RT-PCR

Real-time RT-PCR Expression Ratio

\begin{tabular}{|c|c|c|c|c|c|c|c|c|c|c|c|}
\hline Accession Number & F/L & $\mathbf{F} / \mathbf{S}$ & $\mathbf{F} / \mathbf{P}$ & $\mathbf{F} / \mathbf{N}$ & F/R & F/L & $\mathbf{F} / \mathbf{S}$ & $\mathbf{F} / \mathbf{P}$ & $\mathbf{F} / \mathbf{N}$ & F/R & Affymetrix Chip ID \\
\hline ACI29092_13.I & 40.3 & 383.3 & 65.1 & 1683.9 & 318.1 & 24.2 & $47.1^{b}$ & 38.2 & $45.4^{\mathrm{b}}$ & $55.1^{\mathrm{b}}$ & Mtr.I6432.I.SI_at \\
\hline ACI48485_10.I & 476.2 & 203.7 & 27.2 & 174.6 & 44.5 & $36.5^{b}$ & $32.9 \mathrm{~b}$ & 22.0 & $34.7^{\mathrm{b}}$ & $29.7^{b}$ & Mtr.20392.I.SI_at \\
\hline ACI409I5_20.I & 169.5 & 101.1 & 18.6 & 481.0 & 178.7 & $1.4^{b}$ & $1.4^{b}$ & $1.3^{\mathrm{b}}$ & $1.3^{\mathrm{b}}$ & $1.6^{b}$ & Mtr.5I688.I.SI_at \\
\hline ACI4II07_50.2 & 38.2 & 33.0 & 17.9 & 114.0 & 97.4 & $\mathrm{n}$ & $\mathrm{n}$ & $\mathrm{n}$ & $\mathrm{n}$ & $\mathrm{n}$ & $\mathrm{n}$ \\
\hline ACI4473I_I5.2I & 64.4 & 44.3 & 33.6 & 61.5 & 16.3 & $0.6^{b}$ & $0.6^{b}$ & $0.8^{\mathrm{b}}$ & $0.8^{\mathrm{b}}$ & $0.8^{\mathrm{b}}$ & Mtr.I9093.I.SI_at \\
\hline ACI50978_I2.I & 235.3 & 198.5 & 48.4 & 14.0 & 16.9 & $\mathrm{n}$ & $\mathrm{n}$ & $\mathrm{n}$ & $\mathrm{n}$ & $\mathrm{n}$ & $\mathrm{n}$ \\
\hline$A C I 4 I 107.5 .6 I$ & 261.1 & 127.8 & 13.3 & 96.4 & 71.5 & $0.9 b$ & $0.9 b$ & $0.8^{b}$ & $0.1^{b}$ & $1.1^{b}$ & Mtr.5I65I.I.SI_at \\
\hline ACI57472_19.I & $60.2^{\mathrm{a}}$ & 92.1 & 13.2 & $61.5^{\mathrm{a}}$ & 113.6 & $\mathrm{n}$ & $\mathrm{n}$ & $\mathrm{n}$ & $\mathrm{n}$ & $\mathrm{n}$ & $\mathrm{n}$ \\
\hline ACI48527_19.14I & 188.4 & 42.1 & 17.3 & 26.5 & 13.0 & $\mathrm{n}$ & $\mathrm{n}$ & $\mathrm{n}$ & $\mathrm{n}$ & $\mathrm{n}$ & $\mathrm{n}$ \\
\hline ACI44726_6.I & 254.7 & 55.2 & 10.9 & $112.7 \mathrm{a}$ & 754.7 & 59.2 & $73.7^{b}$ & 7.6 & 89.2 & $97.9 \mathrm{~b}$ & Mtr.I9024.I.SI_at \\
\hline ACI57488_I6.I & $7053.2^{\mathrm{a}}$ & $14||$. & 18.7 & 81.8 & 10.7 & $\mathrm{n}$ & $\mathrm{n}$ & $\mathrm{n}$ & $\mathrm{n}$ & $\mathrm{n}$ & $\mathrm{n}$ \\
\hline ACI23899_15.18I & 10.2 & 92.2 & 19.1 & 62.8 & 24.9 & $0.9 \mathrm{~b}$ & $0.5^{b}$ & $0.8^{b}$ & $0.1^{b}$ & $0.8^{b}$ & Mtr.520I5.I.SI_at \\
\hline
\end{tabular}

A TF gene was considered organ-enhanced if transcript levels for that gene were more than I0-fold higher in one organ than in any other organ. Transcript ratios were calculated using the mean of three biological replicates for each organ. Data from qRT-PCR are compared with data for the same RNA samples obtained from Affymetrix Gene chips [38]. Affymetrix data were normalized using the Robust Multiarray Average (RMA) method, as described by [38], prior to calculation of ratios. Data in bold represent the lowest transcript ratio of the corresponding gene across all organs. $\mathrm{n}=$ not present on Affymetrix chip; $\mathrm{a}=\mathrm{Ct}>40$ in two or three biological replicates of denominator organ; $\mathrm{b}=$ transcript called 'absent' by Affymetrix software in two or three biological replicates of denominator organ. $L=$ leaf; $S=$ stem; $P=$ pod; $F=$ flower; $R=$ root; $N=$ nodule. 
reagent, using an electronic Eppendorf multipipette. Reaction plates were sealed with a transparent adhesive cover before proceeding (Applied Biosystems, Foster City, CA, USA). All templates were amplified using the following standard PCR protocol: $50^{\circ} \mathrm{C}$ for $2 \mathrm{~min} ; 95^{\circ} \mathrm{C}$ for $10 \mathrm{~min}$; 40 cycles of $95^{\circ} \mathrm{C}$ for $15 \mathrm{sec}$ and $60^{\circ} \mathrm{C}$ for $1 \mathrm{~min}$, and $\mathrm{SYBR}^{\circledast}$ Green fluorescence was measured continuously. Melting curves were generated after 40 cycles by heating the sample up to $95^{\circ} \mathrm{C}$ for $15 \mathrm{sec}$ followed by cooling down to $60^{\circ} \mathrm{C}$ for $15 \mathrm{~s}$ and heating the samples to $95^{\circ} \mathrm{C}$ for $15 \mathrm{sec}$.

Data analysis was performed with the SDS 2.2.1 software (Applied Biosystems). To determine the threshold cycle value $\left(\mathrm{C}_{\mathrm{T}}\right)$ for each PCR reaction, the threshold $\left(\Delta R_{\mathrm{n}}\right)$ was set within the logarithmic amplification phase. All amplification plots were analyzed with an $\Delta R_{\mathrm{n}}$ of 0.2. PCR efficiency (E) was estimated using LinReg software with data obtained from the exponential phase of each individual amplification plot and the equation $(1+\mathrm{E})=10^{\text {slope }}[31]$. To compare data from different PCR runs and different cDNA samples, $\mathrm{C}_{\mathrm{T}}$ values were normalized against the geometric mean of four reference genes (Ubquitin, PPRep, PDF2, and PTB), whose transcript levels were most stable across the biological samples analyzed. The average of the geometric mean of these four genes for all 18 samples was $\mathrm{C}_{\mathrm{T}} 21.23 \pm \mathrm{SD} 1.15$. For normalization, the mean reference gene $\mathrm{C}_{\mathrm{T}}$ value was substracted from the $\mathrm{C}_{\mathrm{T}}$ value of the $\mathrm{TF}$ gene of interest, yielding a $\Delta \mathrm{C}_{\mathrm{T}}$ value. The expression ratios for the identification of organ-enhanced genes were obtained using the following formula on all 30 organ combinations: $(1+\mathrm{E})^{\Delta \Delta \mathrm{C}_{\mathrm{T}}}$, where $\Delta \Delta \mathrm{C}_{\mathrm{T}}$ was calculated by $\Delta \mathrm{C}_{\mathrm{TA}}$ minus $\Delta \mathrm{C}_{\mathrm{Tb}}$, $\mathrm{A}$ and $\mathrm{B}$ are averages of three biological replicates of the two organs being compared, and $E$ is the PCR efficiency. Dissociation curves were analysed using SDS 2.2.1 software (Applied Biosystems). RT-PCR products were resolved on $3 \%(\mathrm{w} / \mathrm{v})$ agarose gels (LE Agarose, Biozym, Oldendorf, Germany) run at $4 \mathrm{~V} \mathrm{~cm}^{-1}$ in TAE TrisAcetate-EDTA buffer, along with a 200-bp DNA-standard ladder (Promega GmbH). A subset of 178 RT-PCR products was sequenced at the JC Venter Institute (Rockville, MD, USA).

\section{Competing interests}

The authors declare that they have no competing interests.

\section{Authors' contributions}

KK performed the experimental work and helped draft the manuscript. W-RS, TC, and MS helped to conceive the project and provided practical advice. MW, FC, and CDT carried out bioinformatic analysis of Medicago TFs, and HW designed gene-specific primers. JCR and YX were responsible for the sequencing and analysis of the PCR products. IT carried out qRT-PCR and TG performed statistical analyses. MU designed and coordinated the project and wrote the manuscript.

\section{Additional material}

\section{Additional file 1}

Complete list of TF genes, primer sequences and corresponding PCR efficiencies. The TF primer platform was established based on the data for the gene models according to SA, specific amplification; NA, no amplification; NS, non-specific amplification. RT-PCR products of primer sequences indicated in bold were sequenced.

Click here for file

[http://www.biomedcentral.com/content/supplementary/17464811-4-18-S1.xls]

\section{Additional file 2}

Complete list of TF genes, gene families and experimental data. Shown are the Medicago gene Accession Numbers (TIGR) in ascending order, the TC number if available, as well as the transcription factor family and the subfamily names. The next columns show experimental results for the realtime RT-PCR reactions performed on six different organs of Medicago in three indipendent biological replicates, as explained in the manuscript. CT $=$ not normalized CT value, $\triangle C T=C T$ value normalized against the geometric mean of 4 house keeping genes; $\triangle \Delta C T=\operatorname{power}($ PCReff; $-\triangle C T)$; $\log 2 \triangle \triangle C T=$ logarithmus of $\triangle C T$.

Click here for file

[http://www.biomedcentral.com/content/supplementary/17464811-4-18-S2.xls]

\section{Acknowledgements}

This work was supported in part by the European Commission FP6 Framework Programme Grain Legume Integrated Project (FOOD-CT-2004506223), the Max Planck Society, the National Research Initiative (NRI) Plant Genome Program of the USDA Cooperative State Research, Education and Extension Service (CSREES), and the Samuel Roberts Noble Foundation.

\section{References}

I. Graham PH, Vance CP: Legumes: importance and constraints to greater use. Plant Physiology 2003, 13 1:872-877.

2. Schauser L, Roussis A, Stiller J, Stougaard J: A plant regulator controlling development of symbiotic root nodules. Nature 1999 , 402(6758): $191-195$.

3. Frugier F, Poirier S, Satiat-Jeunemaitre B, Kondorosi A, Crespi M: A Kruppel-like zinc finger protein is involved in nitrogen-fixing root nodule organogenesis. Genes Dev 2000, I4(4):475-482.

4. Nishimura R, Ohmori M, Fujita H, Kawaguchi M: A Lotus basic leucine zipper protein with a RING-finger motif negatively regulates the developmental program of nodulation. Proceedings of the National Academy of Sciences of the United States of America 2002, 99(23): 15206-15210.

5. Gronlund M, Gustafsen $C$, Roussis A, Jensen D, Nielsen LP, Marcker $\mathrm{KA}$, Jensen EO: The Lotus japonicus ndx gene family is involved in nodule function and maintenance. Plant Molecular Biology 2003, 52(2):303-316.

6. Kaló P, Gleason C, Edwards A, Marsh J, Mitra RM, Hirsch S, Jakab J, Sims S, Long SR, Rogers J, Kiss GB, Downie JA, Oldroyd GED: Nodulation signaling in legumes requires NSP2, a member of the 
GRAS family of transcriptional regulators. Science 2005, 308(5729): 1786-1789.

7. Smit P, Raedts J, Portyanko V, Debelle F, Gough C, Bisseling T, Geurts R: NSPI of the GRAS protein family is essential for rhizobial Nod factor-induced transcription. Science 2005, 308(5729): |789-|79|.

8. Combier JP, Frugier F, de Billy F, Boualem A, El-Yahyaoui F, Moreau S, Vernie T, Ott T, Gamas P, Crespi M, Niebel A: MtHAP2-I is a key transcriptional regulator of symbiotic nodule development regulated by microRNAl69 in Medicago truncatula. Genes \& Development 2006, 20(22):3084-3088.

9. Middleton PH, Jakab J, Penmetsa RV, Starker CG, Doll J, Kaló P, Prabhu R, Marsh JF, Mitra RM, Kereszt A, Dudas B, VandenBosch K, Long SR, Cook DR, Kiss GB, Oldroyd GE: An ERF transcription factor in Medicago truncatula that is essential for Nod factor signal transduction. Plant Cell 2007, I 9(4): I22I-I 234.

10. Riechmann JL, Heard J, Martin G, Reuber L, Jiang CZ, Keddie J, Adam L, Pineda O, Ratcliffe OJ, Samaha RR, Creelman R, Pilgrim M, Broun P, Zhang JZ, Ghandehari D, Sherman BK, Yu GL: Arabidopsis transcription factors: Genome-wide comparative analysis among eukaryotes. Science 2000, 290(5499):2105-2110.

II. Udvardi MK, Kakar K, Wandrey M, Montanari O, Murray J, Andriankaja A, Zhang JY, Benedito V, Hofer JMI, Chueng F, Town CD: Legume Transcription Factors: Global Regulators of Plant Development and Response to the Environment. Plant Physiol 2007, I 44(2):538-549.

12. Riechmann JL: Transcriptional Regulation: a Genomic Overview. In The Arabidopsis Book Edited by: Somerville CR, Meyerowitz EM. The American Society of Plant Biologists, Rockville; 2002.

13. Alonso JM, Ecker JR: Moving forward in reverse: genetic technologies to enable genome-wide phenomic screens in Arabidopsis. Nat Rev Genet 2006, 7(7):524-536.

14. Young ND, Cannon SB, Sato S, Kim D, Cook DR, Town CD, Roe BA, Tabata S: Sequencing the genespaces of Medicago truncatula and Lotus japonicus. Plant Physiol 2005, I37(4): I I74-I I I I

15. El-Yahyaoui F, Küster H, Amor BB, Hohnjec N, Pühler A, Becker A, Gouzy J, Vernié T, Gough C, Niebel A, Godiard L, Gamas P: Expression profiling in Medicago truncatula identifies more than $\mathbf{7 5 0}$ genes differentially expressed during nodulation, including many potential regulators of the symbiotic program. Plant Physiology 2004, I36(2):3159-3176.

16. Hohnjec N, Vieweg MF, Pühler A, Becker A, Küster H: Overlaps in the transcriptional profiles of Medicago truncatula roots inoculated with two different Glomus fungi provide insights into the genetic program activated during arbuscular mycorrhiza. Plant Physiol 2005, I37(4): I 283-I30|

17. Holmes P, Goffard N, Weiller GF, Rolfe BG, Imin N: Transcriptional profiling of Medicago truncatula meristematic root cells. BMC Plant Biol 2008, 8(I):2I.

18. Horak CE, Snyder M: Global analysis of gene expression in yeast. Funct Integr Genomics 2002, 2: 17I- 180.

19. Czechowski T, Bari RP, Stitt M, Scheible WR, Udvardi MK: Realtime RT-PCR profiling of over 1400 Arabidopsis transcription factors: unprecedented sensitivity reveals novel rootand shoot-specific genes. Plant Journal 2004, 38(2):366-379.

20. Caldana C, Scheible WR, Mueller-Roeber B, Ruzicic S: A quantitative RT-PCR platform for high-throughput expression profiling of $\mathbf{2 5 0 0}$ rice transcription factors. Plant Methods 2007, 3:7.

21. Scheible WR, Morcuende R, Czechowski T, Fritz C, Osuna D, Palacios-Rojas N, Schindelasch D, Thimm O, Udvardi MK, Stitt M: Genome-wide reprogramming of primary and secondary metabolism, protein synthesis, cellular growth processes, and the regulatory infrastructure of Arabidopsis in response to nitrogen. Plant Physiology 2004, I 36(I):2483-2499.

22. McGrath KC, Dombrecht B, Manners JM, Schenk PM, Edgar Cl, Maclean DJ, Scheible WR, Udvardi MK, Kazan K: Repressor- and activator-type ethylene response factors functioning in jasmonate signaling and disease resistance identified via a genome-wide screen of Arabidopsis transcription factor gene expression. Plant Physiol 2005, I39(2):949-959.

23. Morcuende R, Bari R, Gibon Y, Zheng W, Pant BD, Bläsing O, Usadel B, Czechowski T, Udvardi MK, Stitt M, Scheible WR: Genome-wide reprogramming of metabolism and regulatory networks of Arabidopsis in response to phosphorus. Plant Cell Environ 2007, 30(I):85-II 2 .
24. Libault M, Wan J, Czechowski T, Udvardi M, Stacey G: Identification of 118 Arabidopsis transcription factor and 30 ubiquitinligase genes responding to chitin, a plant-defense elicitor. Mol Plant Microbe Interact 2007, 20(8):900-9II.

25. Guo A, He K, Liu D, Bai S, Gu X, Wei L, Luo J: DATF: a database of Arabidopsis transcription factors. Bioinformatics 2005 , 2I( I 0):2568-2569.

26. lida K, Seki M, Sakurai T, Satou M, Akiyama K, Toyoda T, Konagaya A, Shinozaki K: RARTF: Database and tools for complete sets of Arabidopsis transcription factors. DNA Res 2005, I 2(4):247-256.

27. InterPro: Database of protein families, domains and sites [http://www.ebi.ac.uk/interpro/]

28. WU-BLAST: Washington University BLAST Archives [http://blast.wustl.edu]

29. NCBI: The National Center for Biotechnology Information [http://www.ncbi.nlm.nih.gov/blast]

30. UniProt: The Universal Protein Resource [http://www.uni prot.org/]

31. Ramakers C, Ruijter JM, Deprez RH, Moorman AF: Assumptionfree analysis of quantitative real-time polymerase chain reaction (PCR) data. Neurosci Lett 2003, 339:62-66.

32. Pay A, Heberle-Bors $\mathrm{E}$, Hirt $\mathrm{H}$ : An alfalfa cDNA encodes a protein with homology to translationally controlled human tumor protein. Plant Molecular Biology 1992, 19:50I-503.

33. Czechowski T, Stitt M, Altmann T, Udvardi MK, Scheible WR: Genome-wide identification and testing of superior reference genes for transcript normalization in Arabidopsis. Plant Physiology 2005, 139:5-17.

34. geNORM software [http://medgen.ugent.be/\%7Ejvdesomp/ genorm]

35. Vandesompele J, De Preter K, Pattyn F, Poppe B, Van Roy N, De Paepe A, Speleman F: Accurate normalization of real-time quantitative RT-PCR data by geometric averaging of multiple internal control genes. Genome Biology 2002, 3:research0034.003I-research0034.00II.

36. Chomczynski P, Mackey K: Modification of the TRI reagent procedure for isolation of RNA from polysaccharide- and proteoglycan-rich sources. Biotechniques 1995, I 9(6):942-945.

37. Rozen S, Skaletsky H: Primer $\mathbf{3}$ on the WWW for general users and for biologist programmers. In Bioinformatics Methods and Protocols: Methods in Molecular Biology Edited by: Krawetz S, Misener S. Totowa, NJ , Humana Press; 2000:365-386.

38. Benedito VA, Torres-Jerez I, Murray JD, Andriankaja A, Allen S, Kakar K, Wandrey M, Verdier J, Zuber H, Ott T, Moreau S, Niebel A, Frickey T, Weiller G, He J, Dai X, Zhao PX, Tang Y, Udvard MK: A gene expression atlas of the model legume Medicago truncatula. Plant Journal 2008, (in press): 